Dhaka Univ. J. Biol. Sci. 19(2): 103-110, 2010 (July)

\title{
SURVIVAL POTENTIALITY OF SHIGELLA BOYDII 15 ATCC12034 IN LABORATORY MICROCOSM USING WATER FROM TWO SOURCES
}

\author{
Sabaria Shah, Nafisa Azmuda, Mohammad Ziaur Rahman, Sirajul Islam Khan, \\ Humaira AKHTER ${ }^{*}$ AND ANOWARA Begum \\ Department of Microbiology, University of Dhaka, Dhaka-1000, Bangladesh \\ Key words: Shigella boydii, Survival, Microcosm, Viable, Nonculturable
}

\begin{abstract}
Shigellosis is a waterborne disease but detection and isolation of Shigella in the water cannot be credibly ascertained even during epidemics. The detection, persistence or survival of Shigella in water is thus quite imperative to control the disease. The present study attempts to study the survival of Shigella in waters of different sources using Shigella boydii 15 ATCC12034 as reference culture. Five microcosms were set up; these were pond water (from two locations), tap water, distilled water and Phosphate Buffer Saline (PBS). Relatively longer bacterial persistence was found in microcosms with pond water as compared to that observed in microcosms with PBS and distilled water. With the initial inoculums of $10^{5} \mathrm{cfu} / \mathrm{ml}$, the strain became nonculturable after 9 and 18 days in PBS and pond water, respectively. But with the inoculum size of $10^{6} \mathrm{cfu} / \mathrm{ml}$, it survived up to 16 to 22 weeks in pond waters from two different sources. The morphological and biochemical characteristics of the bacteria remained unchanged over this time. Fluorescent microscopy and PCR were carried out to detect the presence of Shigella boydii 15 in the waters after it became nonculturable in conventional nutrient media. The survival of Shigella in water was possibly inoculum's size dependent; its presence might diminish with time due to lack of nutrients and shifting of physicochemical factors, etc. in water.
\end{abstract}

\section{Introduction}

Diarrhoea continues to be one of the leading causes of morbidity and mortality in the world and is ranked fourth as a cause of death.(1) Even though economic development and progress in health care delivery are expected to catalyze substantial improvements in infectious-disease related morbidity and mortality during the next 30 years, it is predicted that diarrhoea will remain a leading health problem.(2) Shigellosis is an important cause of diarrhoeal deaths. Shigella spp. cause an estimated 1 million deaths world-wide and 163 million cases of dysentery annually, predominantly in children younger than 5 years of age in developing countries.(3) Shigellosis is endemic in Bangladesh, and it is estimated that dysentery accounts for $20 \%$ of deaths related to diarrhoea among children.(4) The genus Shigella, causing shigellosis, is comprised of four species, namely S. flexneri, S. dysenteriae, S. boydii and S. sonnei. Clinical infection can

*Corresponding author: <nhsks123@yahoo.com>. 
occur with transmission of as few as 10 Shigella.(5) The prevalence of the serotypes of $S$. flexneri in Bangladesh has been described to have a temporal variation in the dominance of different subserotypes. The emergence of some atypical serotypes of $S$. flexneri has also been reported.(6) There are no reports of outbreaks caused by the serotypes of $S$. dysenteriae other than serotype 1 in Bangladesh or any other part of the world.(7) Surprisingly, S. boydii, which is thought to be relatively rare, is responsible for nearly one-quarter of shigellosis episodes in Bangladesh lately.(8)

Open waters in the environment play an important role to spread diarrhoeal disease in the community and the presence of Shigella in environmental waters has been reported.(9) Although contaminated water is a major causative agent for shigellosis, until now there is little or no credible report on isolation and recovery of Shigella from aquatic environment. Probably, the Shigellae are fragile or might remain in a state of dormancy or might be starved, injured or stressed. In water, there may be lack of appropriate nutrients or growth factors and the physiological factors may not be favorable for cell resuscitation or repair. There are also reports that cells may undergo "viable but nonculturable" (VBNC) state when exposed longer to some environmental conditions.(10) This phenomenon implies that metabolically active cells are incapable of growth on media normally supporting the growth of those cells. Although other waterborne pathogens like Vibrio and Salmonella have already been detected by routine culture means in water. (11) Shigella in water samples still remains an enigma. Probably they enter into the viable but nonculturable (VBNC) state. Such Shigellae can be detected by techniques, which are culture independent, such as PCR (Polymerase Chain Reaction), fluorescent microscopy etc. Therefore, attempts were taken to detect the survival potentiality of Shigella boydii 15 ATCC 12034 in water.

\section{Materials and Methods}

Shigella boydii 15 ATCC12034 strain was obtained from the Department of Microbiology, University of Dhaka and used for survival study of Shigella spp. in laboratory microcosm. The strain was streaked on nutrient agar plate and incubated at $37^{\circ} \mathrm{C}$ for overnight. Gram staining, biochemical and serological tests and antibiogram were performed according to the standard procedures to reconfirm the strain.(10)

A loopful of freshly cultured Shigella boydii 15 strains was suspended in the test tube containing $10 \mathrm{ml}$ of sterile normal saline. It was then vortexed to prepare a homogenous cell suspension. The optical density of the suspension at $\mathrm{A}_{600}$ was set at 0.11 and 0.28 with a spectrophotometer to prepare the desired concentration of cell suspension of about $10^{5}$ and $10^{6} \mathrm{cells} / \mathrm{ml}$, respectively. The number of cells per $\mathrm{ml}$ was then assessed by viable counts by the drop plate technique.(12)

Seven $250 \mathrm{~m} 1$ conical flasks were taken for microcosm study. The following five different types of microcosms were set in the environmental laboratory of the 
Department of Microbiology:

1. Shahidullah Hall pond water with initial inoculum density of $10^{5} \mathrm{cell} / \mathrm{s} / \mathrm{ml}$.

2. Shahidullah Hall pond water with initial inoculum density of $10^{6} \mathrm{cells} / \mathrm{ml}$.

3. Jagannath Hall pond water with initial inoculum density of $10^{6} \mathrm{cell} / \mathrm{s} / \mathrm{ml}$.

4. Phosphate Buffer Saline (PBS) with initial inoculum density of $10^{5} \mathrm{cells} / \mathrm{ml}$.

5. Distilled water with initial inoculum density of $10^{5}$ cells $/ \mathrm{ml}$.

Each water samples and the PBS used for setting the microcosms were autoclaved for sterilization before use. Before inoculation, the load of microorganisms present in all the flasks was checked to confirm that the water was sterile to avoid any contamination.

Microcosm flasks were kept in a shaking incubator each day for several hours for providing aeration and agitation. Samples were taken on day $0,1,2,5,7,8,9,12,15,18$ from the flasks containing PBS and Shahidullah Hall pond water $\left(10^{5} \mathrm{CFU} / \mathrm{ml}\right)$. In case of Shahidullah Hall pond water $\left(10^{6} \mathrm{CFU} / \mathrm{ml}\right)$ and Jagannath Hall $\left(10^{6} \mathrm{CFU} / \mathrm{ml}\right)$, the samples were taken on week $0,2,4,6,8,10,12,14,16,18,20$ and 22. Samples were diluted appropriately and number of $\mathrm{CFU}$ of total viable cell counts were assayed on selective MacConkey agar medium and nutrient agar plates following the drop plate method. Finally, a plot of time intervals in days versus $\log$ of $\mathrm{CFU} / \mathrm{ml}$ of water sample was prepared for each type of microcosms.

A number of physicochemical parameters such as conductivity, salinity and total dissolved solid (TDS) were measured in pond waters of Shahidullah Hall and Jagannath Hall by conductivity meter (HACH, USA). The $\mathrm{pH}$ was measured using $\mathrm{pH}$-fix 0-14 strip (Fisher, UK). This was done for both sterile and nonsterile pond waters to assess their effects on viability of Shigella boydii.

Sample $(1.5 \mathrm{ml})$ was taken from each microcosm in an Eppendorf and centrifuged at $12000 \mathrm{rpm}$ for 10 minutes. The pellet was suspended in $100 \mu \mathrm{l}$ normal saline and vortexed. Thirty micolitre of the suspension from each eppendorf was taken on $(4,6-$ Diamine 2-Phenyl-Indole (DAPI) membrane and semidried. Ten microlitre of DAPI solution was then added and was incubated at $37^{\circ} \mathrm{C}$ for 30 minutes. Finally, the viability count was taken under the fluorescent microscope.

PCR was carried out for genes specific for virulent properties of Shigella, using chromosomal DNA as template. PCR reactions were carried out with an initial denaturation step at $94^{\circ} \mathrm{C}$ for $3 \mathrm{~min}$; followed by 35 cycles of $94^{\circ} \mathrm{C}, 1 \mathrm{~min} ; 55^{\circ} \mathrm{C}$ for $1 \mathrm{~min}$ $30 \mathrm{sec} ; 72^{\circ} \mathrm{C}, 1 \mathrm{~min} 30 \mathrm{sec}$, with the final extension of $7 \mathrm{~min}$ at $72^{\circ} \mathrm{C} .{ }^{(9)}$ Overnight fresh culture of the isolates at $37^{\circ} \mathrm{C}$ in nutrient broth was subjected to chromosomal DNA extraction and purification according to the procedure described previously ${ }^{(9)}$. The PCR products were later electrophoresed in $1 \%$ agarose gel. 


\section{Results and Discussion}

In the present study, Shigella boydii 15 ATCC12034 was used as reference culture to observe the survival of Shigella in waters of different sources. The purity of the strain was confirmed by microscopic, morphological, cultural, serological and biochemical studies. Survival of Shigella boydii on water was considered as their ability to multiply and to form colonies on routine culture media. Five different types of microcosms were set with autoclaved pond water from two different places, autocolaved distilled water and autoclaved PBS and Shigella boydii 15 was used with different inoculum size. An initial inoculum of $10^{5} \mathrm{CFU} / \mathrm{ml}$ was taken to observe the viability pattern of Shigella boydii 15 in autoclaved distilled water and no growth was found after 24 hours possibly due to unavailability of nutrients. Culturability of Shigella boydii 15 in autoclaved PBS and pond water of Shahidullah Hall was assayed by viable plate count (Fig. 1). Initially the inoculum was $10^{5} \mathrm{CFU} / \mathrm{ml}$. There was a sharp decrease from the very beginning of the inoculation in the viable count and no cell was found after 9 days in case of PBS whereas the bacteria survived up to 18 days in autoclaved pond water (Fig. 1).

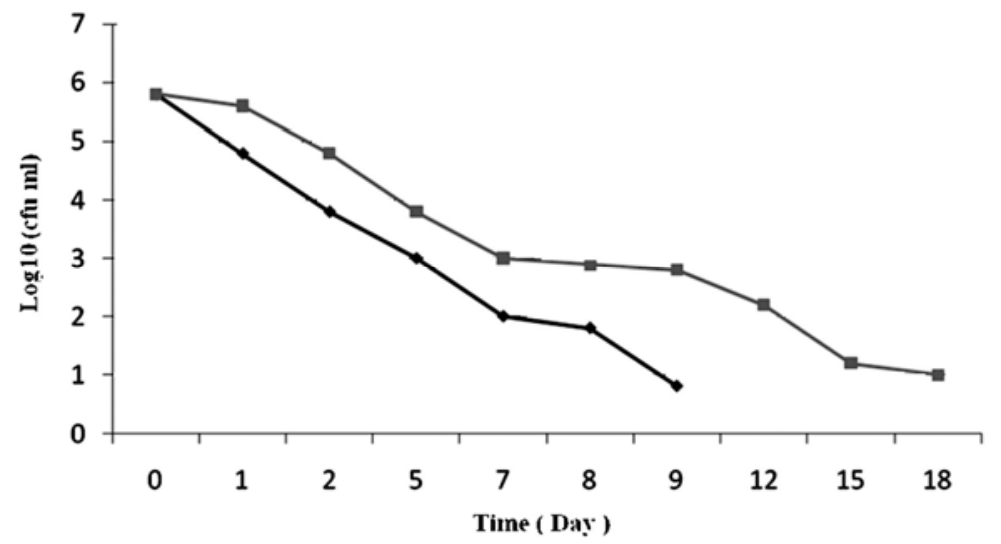

Fig. 1. Survivality of Shigella boydii 15 ATCC 12034 in autoclaved pond water of Shahidullah Hall and phosphate buffer saline (PBS). ----- autoclaved water of Shahidullah hall , -- -- autoclaved PBS.

Culturability in autoclaved pond water of Jagannath Hall $\left(10^{6} \mathrm{CFU} / \mathrm{ml}\right)$ was found to continue for 16 weeks. However, the gradual fall of cell count was observed with time (Fig. 2). The cell count was taken up to 22 weeks and a gradual decrease in cell number was observed in autoclaved pond water of Shahidullah Hall initially containing $10^{6} \mathrm{CFU} / \mathrm{ml}$ (Fig. 2). The bacterial strain was found to grow in MacConkey plates until 150 days. However, due to time constrain further observation could not be continued.

In a previous study, the viability data concluded that inoculum size was the impact factor for the persistence of the microorganism. ${ }^{(10)}$ The findings of this study elucidate 
that at higher density of inoculums, the persistence was longer as compared to lower density. So, in the microcosm with $10^{6} \mathrm{CFU} / \mathrm{ml}$ inoculums density, the survival was observed for longer days (Fig. 2). The lower cell concentration in the natural water bodies might be a reason for lower survivability coupled with constraint for isolation and recovery of bacteria like Shigella. Its persistence in autoclaved water suggests its survival in nature may be limited by biological interactions. One important fact comes out of this experiment was that autoclaving enhances the availability of dissolved organic carbon, perhaps producing a better carbon source for Shigella boydii 15 than normal pond water. Other beneficial effects of autoclaving are destruction of bacteriophages and inactivation of thermolabile toxic substances such as antibiotics.

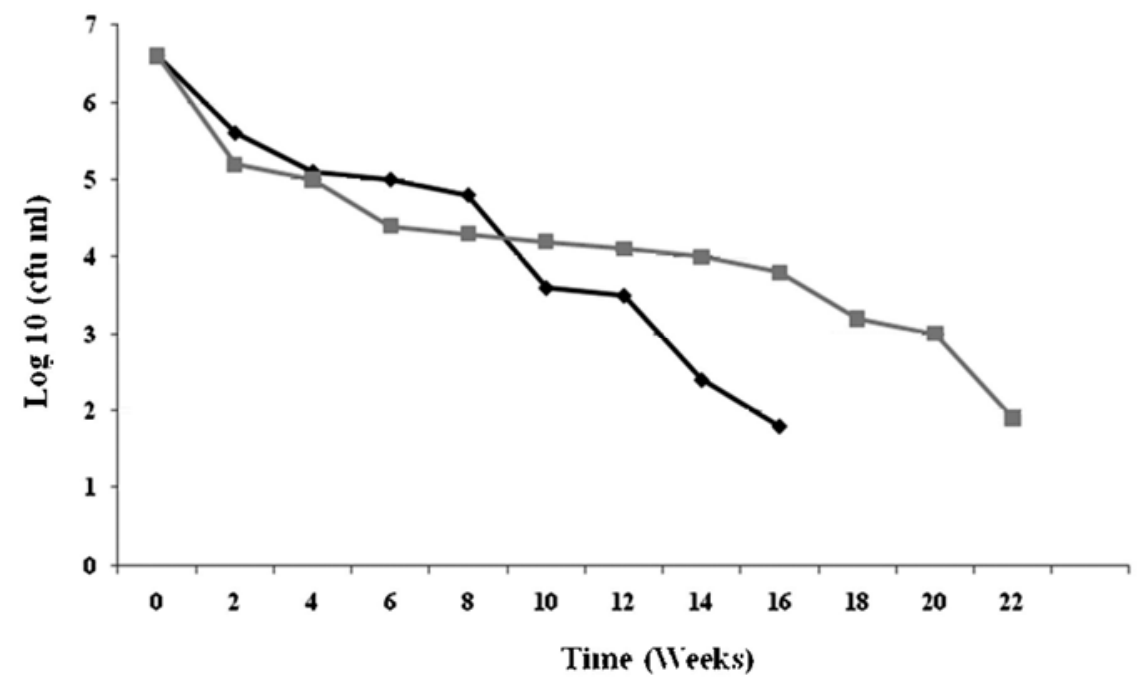

Fig. 2. Survivality of Shigella boydii 15 ATCC 12034 in autoclaved pond water of Shahidullah Hall and Jagannath Hall. --ø-- Shahidullah Hall , -- -- Jagannath Hall.

Various physico-chemical parameters (conductivity, salinity, TDS and $\mathrm{pH}$ ) of the pond waters from Shahhidullah Hall and Jagannath Hall were measured to detect their effects on the survivability of the bacterium (Table 1). These were measured for both sterile and nonsterile water. The parameters were found to be similar for both of the waters but these were relatively lower for pond water of Shahidullah Hall in which longer survivability was observed as compared to Jagannath Hall pond water. Thus the occurrence of Shigella spp. in the environment might also be influenced by the same parameters.

When the bacteria became nonculturable on conventional nutrient agar plates, direct detection for viable cells was done by DAPI staining to see whether they were metabolically active or dead. This was done for autoclaved pond water of Shahidullah Hall initially containing $10^{5} \mathrm{CFU} / \mathrm{ml}$ (Fig. 1), autoclaved pond water of Jagannath Hall 
(Fig. 2), autoclaved distilled water and autoclaved PBS (Fig. 1). With no visible growth on to the media the microcosms were kept for another $24 \mathrm{hrs}$ to ensure the absence of even a single cultivable bacterium. Live cells when stained will fluoresce blue under fluorescent microscope and absence of blue cells under microscope indicates the absence of metabolically active cells. No blue fluorescence was observed that indicated all cells were metabolically inactive (Data not shown).

Table 1. Physico-chemical properties of pond waters from Shahidulla Hall and Jagannath Hall before and after autoclaving.

\begin{tabular}{lllc}
\hline & Parameters & \multicolumn{2}{c}{ Pond water } \\
\cline { 3 - 4 } & & Shahidullah Hall & Jagannath Hall \\
\hline Before autoclaving & & & \\
& Conductivity $(\mu \mathrm{S} / \mathrm{cm})$ & 274 & 472 \\
& Salinity $(\%)$ & 0.10 & 0.20 \\
& $\mathrm{TDS}(\mathrm{mg} / \mathrm{l})$ & 137.1 & 236 \\
After autoclaving & $\mathrm{pH}$ & 7.20 & 7.00 \\
& & & 426 \\
& Conductivity $(\mu \mathrm{S} / \mathrm{cm})$ & 287 & 0.20 \\
& Salinity $(\%)$ & 0.10 & 213 \\
& TDS $(\mathrm{mg} / \mathrm{l})$ & 143.70 & 7.00 \\
\hline
\end{tabular}

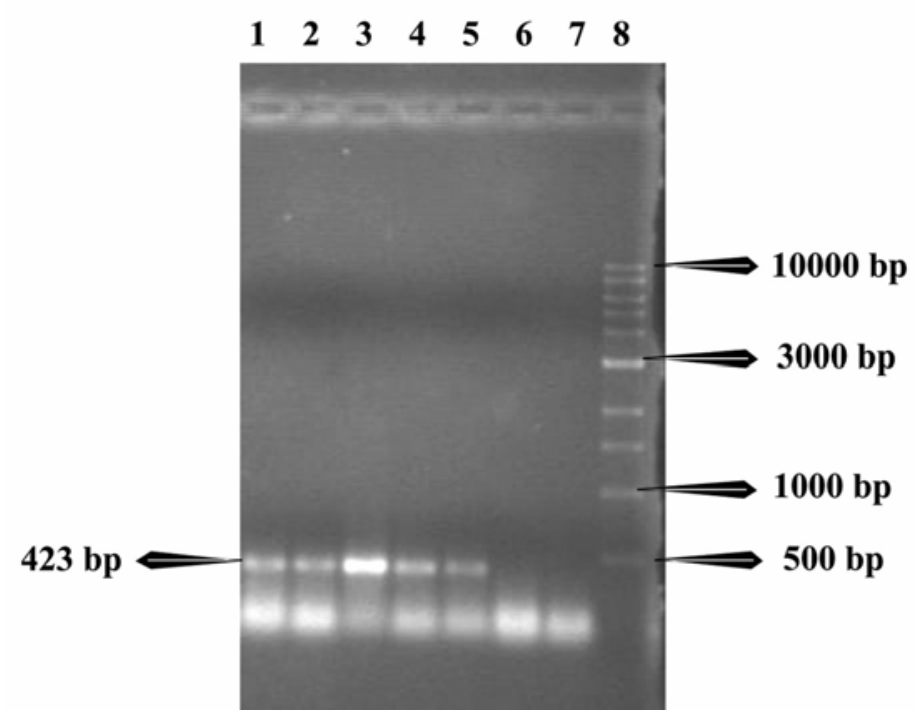

Fig. 3. Amplified product of $i p a \mathrm{H}$ gene. Lane 1 : DNA extracted from pond water of Shahidullah Hall $\left(10^{6} \mathrm{CFU} / \mathrm{ml}\right)$, Lane 2: DNA extracted from pond water of Jagannath Hall $\left(10^{6} \mathrm{CFU} / \mathrm{ml}\right)$, Lane 3: positive control, Lane 4: DNA extracted from pond water of Shahidullah Hall $\left(10^{5} \mathrm{CFU} / \mathrm{ml}\right)$, Lane 5: DNA extracted from pond water of Jagannath Hall $\left(10^{5} \mathrm{CFU} / \mathrm{ml}\right)$, Lanes 6 and 7: Negative control, Lane 8: $1 \mathrm{~kb}$ marker. 
PCR analysis was carried out to detect the presence of virulent gene ipaH (invasive plasmid associated $\mathrm{H}$ gene in Shigella spp.) and ipaBCD for autoclaved pond water of Shahidullah Hall and Jagannath Hall initially containing inoculums $10^{5} \mathrm{CFU} / \mathrm{ml}$ and $10^{6}$ $\mathrm{CFU} / \mathrm{ml}$ and the bacterial cells could not be recovered by plating method that means bacteria might have undergone to the VBNC state. Both ipaH and ipaBCD genes are widely used for detection of Shigella spp. in water and other environmental sources. $(9,13)$ All four samples gave bands of $423 \mathrm{bp}$ (Fig. 3), an expected size of primers specific to ipaH gene which correlate that the strain may be in VBNC state but cannot form colony due to different physico-chemical stresses. All four samples taken from microcosms containing pond waters of Shahidullah Hall $\left(10^{6}\right.$ and $\left.10^{5} \mathrm{CFU} / \mathrm{ml}\right)$ and Jagannath Hall $\left(10^{6}\right.$ and $10^{5} \mathrm{CFU} / \mathrm{ml}$ ) gave negative result after PCR for ipaBCD gene. Thus it could be assumed that the ipaBCD gene might be lost from the strain in course of time of their survival (Data not shown).

Therefore, it could be concluded that the survival potentiality of Shigella boydii 15 ATCC 12034 was time and inoculums size dependant. After certain period, the strain became nonculturable on conventional nutrient plate but still their virulent gene was found to be present. So, further detailed study is needed for understanding the survival mechanism of Shigella in natural water.

\section{References}

1. Murray CJ and AD Lopez 1997a. Mortality by cause for eight regions of the world: Global burden of disease study. Lancet. 349: 1269-1276.

2. Murray CJ and AD Lopez 1997b. Alternative projections of mortality and disability by cause, 1990-2020: global burden of disease study. Lancet. 349:1498-1504.

3. Kotloff KL, JP Winickoff, B Ivanoff, JD Clemens, DL Swerdlow, PJ Sansonetti, GK Adak and MM Levine 1999. Global burden of Shigella infection: Implications for vaccine development and implementation of control strategies. Bull. WHO 77: 651-666.

4. Victora CG, SRA Huttly, SC Fuchs, FC Barros, M Garenne and O Leroy 1993. International differences in clinical patterns of diarrhoeal deaths: A comparison of children from Brazil, Senegal, Bangladesh and India. J. Diarr. Dis. Res. 11: 25-29.

5. DuPont HL, MM Levine, RB Hornick and SB Formal 1989. Inoculum size in shigellosis and implications for expected mode of transmission. J. Infect. Dis. 159: 1126-1128.

6. Talukder KA, DK Dutta, A Safa, M Ansaruzzaman, M, F Hasan, K Alam, KMN Islam, NIA Carlin, GB Nair and DA Sack. 2001. Altering trends in the dominance of Shigella flexneri serotypes and emergence of serologically atypical S. flexneri strains in Dhaka, Bangladesh. J. Clin. Microbiol. 39: 3757-3759.

7. Talukder KA, MA Islam, BK Khajanchi, DK Dutta, Z Islam, A Safa, K Alam, A Hossain, GB Nair and DA Sack. 2003. Temporal shifts in the dominance of serotypes of Shigella dysenteriae from 1999 to 2002 in Dhaka, Bangladesh. J. Clin. Microbiol. 41: 5053-5058. 
8. Seidlein LV, DR Kim, M Ali, H Lee, X Wang, VD Thiem, DG Canh, W chaicumpa, MD Agtini, A Hossain, ZA Bhutta, C Mason, O Sethabuta, KA Talukder, GB Nair, JL Deen, Kotloff and J Clemens 2006. A multicentre study of Shigella diarrhoea in six asian countries: disease burden, clinical manifestations, and microbiology. PLoS. Med. 3(9): e353.

9. Faruque SM, R Khan, M Kamruzzaman, S Yamasaki, QS Ahmad,T Azim, GB Nair, Y Takeda and DA Sack 2002. Isolation of Shigella dysenteriae type 1 and S. flexneri strains from surface waters in Bangladesh : Comparative molecular Analysisis of environmental Shigella isolates versus clinical strains. Appl. Env. Microbiol. 68(8): 3908-3913.

10. Sultana M., MZ Rahman, NK Birkeland and SI Khan 2005. Survival of Shigella flexneri cells in Laboratory Microcosms. Bangladesh J. Microbiol. 22(1): 19-22.

11. Reissbrodt R, I Rienaecker, JM Romanova, PP Freestone, RD Haigh, M Lyte, H Tschape and PH Williams 2002. Resuscitation of Salmonella enterica serovar typhimurium and enterohemorrhagic Escherichia coli from the viable but non- culturable state by heat stable enterobacterial autoinducer. Appl. Env. Microbiol. 68(10): 4788-4794.

12. Hoben HJ and P Somesagaron 1982. Comparison of the pour, spread and drop plate methods for enumeration of Rhizobium spp. in inoculates made from preseterilized peat. Appl Env. Microbiol. 44:1242-1247.

13. Sharma A, SK Singh and D Bajpai 2010. Phenotypic and genotypic characterization of Shigella spp. with reference to its virulence genes and antibiogram. Analysis from river Narmada. Microbiological Res. 165(1): 39-42. 